\title{
Psychopathy and the Positive and Negative Affect Schedule (PANAS) as the Predictors of Totalitarian Political Ideology
}

\author{
Zlatko Šram ${ }^{1}$ \\ Croatian Center for Applied Social Reserach
}

\begin{abstract}
The present study has two goals. The first goal is to investigate whether a high need for the government-imposed security and social regulation, the acceptance of living in a dictatorship, the limitations and denial of individual freedom and the support to repressive methods and procedures are in such high mutual correlations that they form a coherent latent dimension of the Totalitarian Political Ideology (TPI). The second goal is to examine whether and which of the psychopathy traits (Interpersonal manipulation, Callous affect, Erratic lifestyle, and Antisocial behaviour) and the PANAS (Positive and Negative affect Schedule as a measure of general affectivity) underlie Totalitarian Political Ideology. The research was carried out on a convenience sample of undergraduate and graduate students from the University of Zagreb $(\mathrm{N}=386)$. It has been found that the Totalitarian Political Ideology is an internally coherent and reliable pattern of political orientations and values. In order to explore how psychopathic traits and positive and Negative affect are associated with the internalization of the Totalitarian Political Ideology (TPI), multiple regression analysis was conducted. Interpersonal manipulation, Callous affect and Negative affect proved to be significant predictors of the TPI scale in positive directions, whereas Erratic lifestyle was a significant predictor of the TPI scale in the negative direction. About $15 \%$ of the variance of the Totalitarian Political Ideology was explained by these personality characteristics. The findings can have both theoretical and practical contributions in understanding the endorsement of totalitarian beliefs.
\end{abstract}

Keywords: psychopathy, negative affectivity, ideology, totalitarianism.

\section{Introduction}

There is a plethora of research papers dealing with the relationships between personality and social attitudes (Sibley, Osborne, \& Duckitt, 2012; for a recent review, see Petrović, 2020), as well as those investigating psychological

1 e-mail: zlatko.sram@appliedsocresearch.com 
underpinnings of political ideology (Cichocka \& Dhont, 2018; Jost, Federico, \& Napier, 2009; Verhulst, Eaves, \& Hatemi, 2012). Namely, a number of personality variables affect the internalization of the specific patterns of ideological attitudes, opinions, and values (e.g. Openness to experience and Sensation seeking have robust negative correlations with political conservatism: Jost, Glaser, Kruglanski, \& Sulloway, 2003). However, there is scarcely any research proposing that psychopathy and Negative affect might exacerbate totalitarian political ideology. The findings that psychopathy may be relevant to political attitudes (Jonason, 2014) are often discarded. In other words, we hypothesize the existence of a singular latent cognitive style factor that turns political values and orientations into totalitarian political ideology that might emerge, under certain historical circumstances and conditions, in both the authoritarian and democratic societies where the radical rightwing and the radical left-wing might jointly collaborate. Given the disastrous consequences that such an extremist ideology might have in the political and social life of a society, this issue calls for a deeper psychological investigation in order to understand the workings of a repressive political ideology. Hence, in this study, we make an attempt to bridge the gap in the literature by examining the relationship between psychopathy, the Positive and Negative affect schedule, and the totalitarian political ideology.

\subsection{Political ideology}

An ideology possesses a discursive superstructure and a functional base or substructure (Jost, Frederico, \& Napier, 2013). A discursive superstructure refers to a set of socially constructed attitudes, values, and beliefs. In other words, political ideology is a "set of beliefs about the proper order of society and how it can be achieved" (Erikson \& Tedin, 2003, pp. 64) or is any "configuration of ideas and attitudes in which the elements are bound together by some form of constraint or functional interdependence" (Converse, 1964, pp. 206). The functional substructure "refers to the constellation of social and psychological needs, goals, and motives that drive political preferences of ordinary citizens (and are therefore served by the discursive contents of ideology)" (Jost et al., 2013, pp. 233). Hence, political ideology serves social psychological functions and motives, which may help to explain why some people are drawn to it. This is in accordance with the theory of political ideology as motivated social cognition (Jost et al., 2003), positing that ideological outcome is the joint product of the discursive superstructure and motivational substructure. In short, political ideology should express social, cognitive, and motivational tendencies on the part of his/her adherent (Jost, 2006). Within the motivational substructure of political ideology, there are three classes of psychological variables: epistemic motives (ideology offers certainty), existential motives (ideology offers security), and relational 
motives (ideology offers solidarity) (Jost, Federico, \& Napier, 2009). Hence, an attitudinal content of political ideology is theorized to stem from social psychological orientations concerning uncertainty and threat (Jost \& Napier, 2012). Namely, in such a theoretical framework, ideologies serve to reduce different uncertainties and threats.

\subsection{Psychopathy}

Psychopathy is conceptualized as a superordinate construct underpinned by four first-order factors: "Interpersonal (glibness/superficial charm, grandiose sense of self-worth, pathological deception, conning/manipulative); Affective (lack of remorse or guilt, shallow affect, callous/lack of empathy, failure to accept responsibility for actions); Lifestyle (need for stimulation/ proneness to boredom, parasitic lifestyle, lack realistic long-term goals, impulsivity, irresponsibility), and Antisocial (poor behaviour controls, early behaviour problems, juvenile delinquency, revocation of conditional release, criminal versatility)" (Neumann, Hare, \& Pardini, 2014). Previous research found that psychopathy predicted conservative ideology (Jonason, 2014), as well as that conservative political opinions were related to psychopathy (Arvan, 2013). We can assume that the content of Totalitarian Political Ideology strongly resembles an ideology that was characteristic for the former communist countries or fascist regimes. In comparison to a modern political democratic perspective, we can consider such a political pattern to be a conservative ideological pattern. Here, the question arises as to what factors of psychopathic traits are related with such a conservative ideology. Lilienfeld, Latzman, Watts, Smith, and Dutton (2014) found that all psychopathic traits, measured by the shortened Psychopathic Personality Inventory-Revised, were positively correlated with conservatism. However, some authors did not find that psychopathy was significantly related to conservatism (Hodson, Hogg, \& MacInnis, 2009). Note that inconclusive findings on the associations between psychopathy and conservatism may result from the fact that psychopathy is operationalized via various models which differ in their content (for a review see Međedović, 2015) - hence, these differences in psychopathy operationalizations may be the source of inconsistency. On the other hand, there is a study showing that the interpersonal-affective traits of psychopathy in particular appear pertinent to political attitudes (Preson \& Anestis, 2018). And, indeed, positive associations between interpersonal/ affective psychopathic traits and conservatism are more probable, due to common characteristics such as the lack of care and low emotional empathy (Međedović \& Petrović, 2016). In contrast, higher disinhibition, non-conformism, impulsiveness, and antisocial behaviour (lifestyle / antisocial psychopathy traits) can be assumed to have negative correlations with conservative attitudes because they are opposite to conventional and traditional values. 


\subsection{Positive and Negative Affect Schedule (PANAS)}

Watson, Clark and Tellegen (1988) developed a 20-item self-report measure of positive and negative affect, labelled "The Positive and Negative Affect Schedule (PANAS)". Positive affect (PA) "reflects the extent to which a person feels enthusiastic, active, and alert" whereas Negative affect (NA) is a dimension of "unpleasurable engagement that subsumes a variety of aversive mood states, including anger, contempt, disgust, guilt, fear, and nervousness" (Watson et al., 1988, pp. 1063). It was found that psychopathy was associated with a high level of Negative affect (NA) (Love \& Holder, 2014) and other measures of negative emotionality (Garofalo, Neumann, Zeigler-Hill, \& Meloy, 2018). So far, we have not found any research investigating the relationship between the PANAS and the patterns of political totalitarianism. However, we can expect positive correlations between the Negative affect and the endorsement of totalitarianism because it has been found previously that Negative affect positively correlates both with the Right Wing Authoritarianism and Social Dominance Orientation (Van Hiel \& Kossowska, 2006); both of these measures may be viewed as the extreme forms of political conservatism.

\subsection{The current study}

Totalitarian Political Ideology (TPI) was defined as a pattern of political attitudes that explain and justify a state of political totalitarianism expressed through: (1) governmental attempt to assert total control of the people's lives, (2) permitting no individual freedoms in order to subordinate individual life to the state authorities, and (3) directing all aspects of individual life through state repression. The concept of Totalitarian Political Ideology was operationalized in terms of four facets: (1) a high need for the governmentimposed security and social regulation, (2) the acceptance of living in a dictatorship under provided circumstances, (3) the limitations and denial of individual freedom, and (4) giving support to applying the state repression methods and control. We hypothesize that all the four facets are in such high mutual correlations that they form a logical, coherent, consistent, and stable latent dimension of the Totalitarian Political Ideology.

The second goal of the study is to find out if personality differences underlie a pattern of the Totalitarian Political Ideology. Given the associations between psychopathy and conservative ideology on the one hand, and the associations between psychopathy and mood disorder on the other, at least between some of their components, we hypothesize that Negative affect, together with Interpersonal and Affective psychopathy traits, may have positive associations with the Totalitarian Political Ideology; on the other hand, Impulsive and Antisocial psychopathy facets should be negatively related to the TPI. In other 
words, we posit that internalization and expression of Totalitarian Political Ideology may be a wider psychological proneness which is largely present in the general population and related to specific personality characteristics.

\section{Materials and methods}

\subsection{Sample and procedure}

A convenience sample of the undergraduate and graduate students from the University of Zagreb was formed, on which research was carried out. The sample consisted of 212 male and 174 female university students. Their age ranged from 18 to $29(\mathrm{M}=20.83, \mathrm{SD}=2.07)$. The study was conducted at the following faculties of the University of Zagreb: the Faculty of Humanities and Social Sciences, Faculty of Political Sciences, Faculty of Kinesiology, Faculty of Natural Sciences and Mathematics, Faculty of Traffic Engineering, and Faculty of Geotechnical Engineering. Participants completed the paper and pencil questionnaires during regularly-scheduled university classes. The faculty authorities officially approved this study. Data collection was organized within a larger social psychological study in May 2016.

\subsection{Materials and methods}

\subsubsection{Assessment of the ideological attitudes}

Totalitarian Political Ideology (TPI) was measured by a seven-item scale that was constructed on the basis of Mahrabian's (1996) attitudinal construct indicating political totalitarianism. Items were rated on a five-point Likert scale, ranging from 1 (disagree strongly) to 5 (agree strongly).

\subsubsection{Assessment of psychopathic traits}

Psychopathy traits were measured with the Self-Report Psychopathy Scale (SRP-4) (Paulhus, Neumann, \& Hare, 2017). It is a 64-item scale assessing four facets of psychopathy: Interpersonal manipulation (16 items), Callous affect (16 items), Erratic lifestyle (16 items), and Antisocial behaviour (16 items). Such a four-factor construct validity of the SRP was supported across a wide diversity of samples (Neal \& Selbom, 2012; Neumann \& Pardini, 2014). The SRP is also a measure with strong convergent and discriminant validity (Mahmut, Menictas, Stevenson, \& Homeward, 2011). The permission to use the SRP was obtained from the instrument's second author, Craig S. Neumann. Participants were asked to state to which extent they agreed with each statement using a five-point Likert scale, ranging from 1 (disagree strongly) to 5 (agree strongly). The translation from English to Croatian and back-translation into English was conducted in an earlier study (Pačić-Turk \& Gajski, 2014). 


\subsubsection{The measure of Positive and Negative affect}

Positive and negative affect were measured by the Positive and Negative Affect Schedule (PANAS) (Watson, Clark, \& Tellegen, 1988). This measure consists of two 10-item mood scales, measuring both the Positive affect (PA) and Negative affect (NA). Emotions such as enthusiasm and alertness are characteristic for PA, whilst the NA is characterized by the emotions such as lethargy and sadness. The PANAS was proved to be a reliable and valid measure of the two constructs (Craford \& Henry, 2004, von Humboldt, Monteiro, \& Leal, 2017).

\section{Results}

\subsection{Exploratory factor analysis of the Totalitarian Political Ideology scale (TPI)}

Exploratory factor analysis (EFA) was performed in order to find out if the indicators used to measure proneness to totalitarian ideology formed a singular latent factor. The Kaiser-Mayer-Olkin measure $(\mathrm{KMO}=0.828)$ and Bartlett's sphericity test $\left(\chi^{2}=633.04, p<0.001\right)$ confirmed that it was appropriate to apply EFA to the data set. EFA yielded a unifactorial solution explaining 44.16 percent of the variance. The factorial loadings ranged between 0.53 and 0.73 . High need for the government-imposed security and social regulation, acceptance of living in a dictatorship under provided circumstances, limitations and denial of individual freedom, and giving support to applying the state repression methods and procedures underlie the latent structure of the Totalitarian Political Ideology (Table 1).

Table 1.

Factor structure of the Totalitarian Political Ideology scale (TPI)

7. The development of strong police forces and national intelligence agencies are of much more importance for our country today than the development of loadings democracy and protecting human rights.

5. The government must limit our individual freedoms in order to function more efficiently and act more justly.

2. For me, government-imposed social order and security are more important than individual freedom.

4. When people don't have enough sense to know what is good for them, the government must step in and, if necessary, use force to show them the way.

6 . The safety of our nation and state must always come before concerns for citizens' rights to privacy or fair trails.

3. In the case of bigger social riots, it is the army that should take over the power in the country. 


\subsection{Reliabilities and the descriptive statistics of the analysed scales}

Internal consistency coefficients were calculated for the SRP and its separate subscales, each consisting of 16 items. Internal consistency, measured by Cronbach's alpha, was considered acceptable if alpha was equal or higher than 0.70 (Nunnaly \& Bernstein, 1994). Internal consistencies, scale homogeneity (mean inter-item correlations), and descriptive statistics for the SRP and its subscales are reported in Table 2. Reliability coefficient for the SRP total score was excellent. Internal consistencies for the subscales of the SRP were found to be acceptable. However, the Callous affect subscale indicated poor scale homogeneity $(\mathrm{MIC}=0.13)$. Since the scale length affected the magnitude of Cronbach's alpha, additional mean inter-item correlations (MIC) indexing scale homogeneity were calculated. MIC was considered acceptable if it was equal to or higher than 0.15 (Clark \& Watson, 1995). The scores for the ASB subscale were much lower compared with the other subscale of the SRP, which is consistent with the findings obtained by Gordts, Uzieblo, Neumann, Van den Bussche, and Rossi (2017). Compared with the scores obtained in a large Belgian community sample (Gordts et al., 2017), in an American community sample (Paulhus et al., 2017), and in another Croatian sample (Međedović, Wertag, \& Sokić, 2018), internal consistency coefficients and other descriptive statistics of the SRP and its subscales in the current sample were very similar. It is worth noting that, in the current study, the values of skewness and kurtosis indicated normal distributions of the scores in the full version of the SRP and all the subscales, except for the Antisocial behaviour scale, which was skewed towards the lower scores.

Regarding PANAS, we first conducted Exploratory factor analysis (EFA) with Promax rotation, which was performed to explore its factor structure. The Kaiser-Meyer-Olkin measure $(\mathrm{KMO}=0.882)$ and Bartlett's sphericity test $\left(\chi^{2}=3491.65, p<0.001\right)$ confirmed that it was appropriate to apply EFA to the data set. Based on theory of the PANAS two-factor structure, we expected that two latent factors would be extracted. EFA yielded two factors indeed, explaining 49.52 percent of the variance. The first factor was labelled Positive affect and the second Negative affect. The loadings of the items on their respective factors can be seen in the Appendix. It is evident that the extracted latent structure captured the underlying mood factors in the sample of the Croatian university students, identical to the original model developed by Watson et al. (1988) and similar to the models developed by Veronese and Pepe (2017).

In Table 2, we can see that in the current study the alpha internal consistencies of the PA scale and the NA scale are acceptably high. This is in accordance with the original version of the PANAS scales (Watson et al., 1998) and the studies carried out on different samples (Serafini, Malin-Mayor, Nich, 
Hunkele, \& Carroll, 2016; von Humboldt et al., 2017). The scores obtained on both scales are normally distributed. The mean scores of the PA and the NA scales are identical as in Serafini and her colleagues' research (2016).

Table 2.

Internal consistencies, mean inter-item correlations, means, standard deviations, skewness and kurtosis statistics for the analysed measures

\begin{tabular}{lccccc}
\hline & $\alpha$ & MIC & $\mathrm{M}(\mathrm{SD})$ & Skewness & Kurtosis \\
\cline { 2 - 6 } SRP-III & .90 & 0.13 & $149.18(26.47)$ & 0.29 & 0.13 \\
Interpersonal manipulation (IPM) & .80 & 0.20 & $43.46(8.97)$ & 0.33 & 0.59 \\
Callous affect (CA) & .71 & 0.13 & $38.59(7.49)$ & 0.24 & 0.18 \\
Erratic life style (ELS) & .77 & 0.18 & $41.53(8.86)$ & 0.15 & -0.20 \\
Antisocial behaviour (ASB) & .74 & 0.22 & $23.56(7.27)$ & 0.91 & 0.34 \\
Positive affect (PA) & .89 & 0.47 & $30.10(6.59)$ & -0.59 & 0.82 \\
Negative affect (NA) & .88 & 0.42 & $20.83(6.90)$ & 0.41 & -0.16 \\
Totalitarian Political Ideology & .77 & 0.34 & $14.93(4.85)$ & 0.28 & -0.54 \\
\hline
\end{tabular}

Finally, we reported internal consistencies, scale homogeneity (mean inter-item correlations), and descriptive statistics for the TPI scale (Table 2). We can see that the reliability coefficient for the TPI scale score, measured with Cronbach's alpha, was relatively high. Having in mind the values of skewness and kurtosis, the distribution of the scores obtained on the TPI scale can be considered normal.

\subsection{Correlations among study variables}

Correlations among study variables are reported in Table 3. We can see that the total SRP score is highly correlated with all its subscales. The magnitude of correlations among the SRP facets suggests an existence of a superordinate psychopathy factor in which psychopathy is underpinned by four correlated facets (Neumann, Hare, \& Newman, 2007; Neumann, Vitacco, \& Mokros, 2016). Principal component analysis proved the existence of such a superordinate model, explaining 62 percent of the total variance $(\mathrm{KMO}=0.76)$ with the following factor loadings: IPM $=0.84, \mathrm{ELS}=0.82$, $\mathrm{CA}=0.77$, and $\mathrm{ASB}=0.70$.

We found a significant negative correlation between the PA and NA scale $(\mathrm{r}=-0.26 ; \mathrm{p}<0.01)$. Though the correlation between these two affect scales is low, sharing only 6 percent of their variance, the hypothesis of complete independence between the PA and NA should be rejected (Craford \& Henry, 2004). It is worth noting we found statistically positive, though low, correlations between the Negative affect (NA) and Interpersonal manipulation (IPM), Erratic lifestyle (ELS), and Antisocial behaviour (ASB). In other words, 
Negative affect underlies the lifestyle-antisocial dimension of psychopathy, encompassing a degree of interpersonal manipulation. If we consider lifestyle-antisocial trait and interpersonal manipulation as socially-deviant behaviours, our findings are in line with research dealing with psychopathy and negative emotionality that found that the social deviance (as a syndrome of psychopathy) is positively associated with negative emotionality (Hick \& Patrick, 2006; Patrick, 1994).

We can see from Table 3 that Totalitarian Political Ideology (TPI) is positively associated with psychopathic facets such as Interpersonal manipulation (IPM), Callous affect (CA), and the Negative affect scale (NA) of PANAS. These findings indicate that the affective-interpersonal dimension of psychopathy and negative emotionality underlie an attitudinal construct such as Totalitarian Political Ideology. It is in line with Preston and Anestis' (2018) research showing that "higher levels of interpersonal-affective psychopathic traits appear more likely to espouse conservative ideologies" (pp. 147).

Table 3.

Correlations among study variables $(n=386)$

\begin{tabular}{lccccccc}
\hline & 1 & 2 & 3 & 4 & 5 & 6 & 7 \\
\cline { 2 - 8 } 1. SRP-III total & & & & & & & \\
2. Interpersonal manipulation (IPM) & $.83^{* *}$ & & & & & & \\
3. Callous affect (CA) & $.76^{* *}$ & $.59^{* *}$ & & & & & \\
4. Erratic lifestyle (ELS) & $.82^{* *}$ & $.57^{* *}$ & $.50^{* *}$ & & & & \\
5. Antisocial behaviour (ASB) & $.72^{* *}$ & $.44^{* *}$ & $.34^{* *}$ & $.49^{* *}$ & & & \\
6. Positive affect (PA) & -.03 & -.03 & -.05 & -.04 & .01 & & \\
7. Negative affect (NA) & $.17^{* *}$ & $.13^{*}$ & .05 & $.20^{* *}$ & $.14^{* *}$ & $-.26^{* *}$ & \\
8. Totalitarian Political Ideology (TPI) & $.15^{* *}$ & $.20^{* *}$ & $.25^{* *}$ & .00 & .04 & .00 & $.14^{* *}$ \\
\hline
\end{tabular}

Notes: ${ }^{\star}-\mathrm{p}<.05 ;{ }^{\star *}-\mathrm{p}<.01$

\subsection{Regression analysis}

In order to explore how psychopathic traits and the positive and Negative affect are associated with the internalization of the Totalitarian Political Ideology (TPI), multiple regression analysis was conducted. The TPI scale was entered as the criterion variable in the regression model, whereas psychopathic traits and the PANAS facets were entered as predictors. Participants' sex, age, and education were controlled in the analysis as well. Standardized regression coefficients are shown as a measure of predictors' independent contribution to the regression.

The results of multiple regression analysis conducted within the total sample are presented in Table 4 . The obtained regression model was statistically significant, $\mathrm{F}(9,376)=7.18, \mathrm{p}<0.001 ; \mathrm{R}^{2}=0.15$. Interpersonal 
manipulation, Callous affect, and Negative affect of the PANAS were proven to be significant predictors of the TPI scale in positive directions, whereas Erratic lifestyle is a significant predictor of the TPI scale in the negative direction. Antisocial behaviour and Positive affect of the PANAS did not significantly predict Totalitarian Political Ideology. About 15\% of the variance of the Totalitarian Political Ideology was explained by the affective-interpersonal dimension of psychopathy, Negative affect, and the absence of an erratic lifestyle.

Table 4.

Multiple regression of the SRP and the PANAS subscales on the Totalitarian Political Ideology scale

\begin{tabular}{lccl}
\hline & $\beta$ & $\mathrm{t}$ & $\mathrm{p}$ \\
\cline { 2 - 4 } Sex & -.16 & -3.14 & .00 \\
Age & -.06 & -1.11 & .27 \\
Education & -.05 & -0.95 & .34 \\
Interpersonal manipulation (IPM) & .19 & 2.91 & .00 \\
Callous affect (CA) & .18 & 2.74 & .01 \\
Erratic lifestyle (ELS) & -.25 & -4.09 & .00 \\
Antisocial behaviour (ASB) & -.00 & -0.08 & .94 \\
Positive affect (PA) & .04 & 0.84 & .41 \\
Negative affect (NA) & .16 & 3.11 & .00 \\
\hline
\end{tabular}

\section{Discussion}

\subsection{Structure of Totalitarian Political Ideology}

The current study examined whether psychopathy and PANAS predicted a syndrome of the Totalitarian Political Ideology. The first goal of the study was to find out whether there was an internally coherent, consistent, and stable latent dimension of an attitudinal construct indicating the existence of Totalitarian Political Ideology (TPI). The results of the exploratory factor analysis revealed that (a) a high need for government-imposed security and social regulation, (b) the acceptance of living in a dictatorship under provided circumstances, (c) the limitations and denial of individual freedom, and (d) giving support to applying the state repression methods and control are in such strong mutual correlations that on the latent level they formed a valid construct of the Totalitarian Political Ideology. In that sense, our first hypothesis was confirmed.

Given the discursive superstructure of ideology (Erickson \& Tedin, 2003; Jost et al., 2013), we can see that Totalitarian Political Ideology indicates a set of beliefs about the proper order of the society (strictly government- 
imposed security and social regulation) and how it can be achieved (through state repression and control, limitations of individual freedoms, and even by accepting a coup d'état and dictatorship under certain circumstances and conditions). It is evident that the latent structure of the TPI is a configuration of attitudes in which the elements are, as Converse (1964) would argue, strongly bound by the form of functional interdependence of both specific state-political aims and means. Given a deeper political psychological meaning of such a pattern of political totalitarianism, we may label it as "repressive statism". Such a political attitudinal profile implicitly indicates the existence of supporting the state-economic protectionism and interventionism, accompanied by giving up personal political freedoms in exchange for a state imposed collective security (Šram, 2016).

The pattern of political totalitarianism can be treated as motivational social cognition (Jost et al., 2003). In other words, Totalitarian Political Ideology or "repressive statism" is the joint product of the discursive and motivational substructure. Within the motivational substructure of the Totalitarian Political Ideology, there are epistemic motives (ideology offers certainty), existential motives (ideology offers security), and relational motives (ideology offers a state repressive protection; social cohesion is gained through repression and dictatorship). Hence, Totalitarian Political Ideology or "repressive statism" is, in line with Jost and Napier (2012), theorized to stem from social psychological orientations concerning uncertainty and threat. In such a theoretical framework, Totalitarian Political Ideology serves to reduce both individual and collective uncertainties and threats by means of state repression methods and procedures that can easily be turned into political dictatorship.

In spite of the fact that the discursive and functional substructures of Totalitarian Political Ideology strongly resemble the totalitarian regime of former communist countries (Šram \& Dulić, 2015), we speculate that such a political psychological defence mechanism might be activated and emerge in the developed democratic systems in certain social, economic, and political circumstances and conditions. If such a pattern of political totalitarianism is clearly recognized within the university students' sample, it is reasonable to expect that it would be recognizable within a general adult population as well (Šram, 2016). Besides, it is worth noting that the distribution of the results gained on the TPI scale does not indicate the characteristics of a socially deviant and pathological political phenomenon but a more general attitude, which can be endorsed by many individuals in a population. This is in line with the findings that even liberals may support authoritarian and totalitarian policies when facing uncertain circumstances (Nail, McGregor, Drinkwater, Steele, \& Thompson, 2009). 


\subsection{Psychological underpinning of the Totalitarian Political Ideology}

The second hypothesis of the current study, concerning the issue of whether psychopathy and PANAS predicted Totalitarian Political Ideology, was also confirmed. The results of correlation and regression analysis have shown that affective-interpersonal dimension of psychopathy (Callous affect and Interpersonal manipulation) and negative emotionality (Negative affect of PANAS) underlie Totalitarian Political Ideology. Positive associations between the NA and TPI are congruent with the previous findings of positive correlations between the NA, Right Wing Authoritarianism, and Social dominance orientation (Van Hiel \& Kossowska, 2006). Findings on the relations between psychopathy and TPI are in line with Preston \& Anestis' (2018) research showing that "higher levels of affective-interpersonal psychopathic traits appear more likely to espouse conservative ideologies" (pp. 147). If Totalitarian Political Ideology is treated as a kind of conservative ideology, our findings did not confirm, as Lilienfeld et al. (2014) argued, that all psychopathic traits were in positive correlation with conservatism or that psychopathy was not significantly related to conservatism, as claimed by Hodson et al. (2009). We previously stated that this heterogeneity in the results regarding psychopathy's associations with conservatism may be contingent on the specific operationalizations of psychopathy because different psychopathy models tend to have different content (Međedović, 2015). We also want to highlight that the part of covariations between Interpersonal psychopathy traits and TPI may be tautological in nature both scales assess characteristics which are similar to Machiavellianism. This shared content may explain at least a part of the shared variation between the two measures. On the other hand, Erratic lifestyle had a significant negative correlation with the Totalitarian Political Ideology, which was expected, whereas Antisocial behaviour was not in any correlation with political totalitarianism.

There are limitations to the present study as well: mono-method assessment (all self-report measures), college student sample, and cross-sectional design. It is important to note that, in future research, psychometric properties of the Totalitarian Political Ideology scale should be examined in ethnically different community samples in Europe. It should also include additional measures of personality and mental disorders that may be correlated with the ideological construct measured in the current research. Nevertheless, the present research contributes to the existing knowledge by confirming the associations between the "dark" personality characteristics, represented by psychopathy, and the proneness to totalitarian ideology. Hence, it may help in future research on the relations between amoral personality dispositions and the extreme right-wing ideology, especially since it seems that the latter is gaining momentum worldwide once again. 
ŠRAM Z.: PSYCHOPATHY AND THE POSITIVE AND NEGATIVE AFFECT SCHEDULE (PANAS)

AS THE PREDICTORS OF TOTALITARIAN POLITICAL IDEOLOGY

\section{References}

Arvan, M. (2013). A lot more bad news for conservatives, and a little bit of bad news for liberals? Moral judgments and the Dark Triad personality traits: A follow-up study. Neuroethics, 6, 51-64. doi:10.1007/s12152-012-9155-7.

Cichocka, A., \& Dhont, K. (2018). The personality basis of political ideology and behavior. In V. Zeigler-Hill, \& T. K. Shackelford (Eds.), The SAGE Handbook of personality and individual differences: Volume III: Applications of personality and individual differences (pp. 323-352), Sage: UK. doi.org/10.4135/9781526451248.n14.

Clark, L. A., \& Watson, D. (1995). Constructing validity: Basic issues in objective scale development. Psychological Assessment, 7, 309-319. doi:10.1037/10403590.7.3.309.

Converse, P. E. (1964). The nature of belief systems in mass publics. In D. Apter (Ed.), Ideology and discontent (pp. 206-261). New York, NY: Free Press.

Craford, J. R., \& Henry, J. D. (2004). The Positive and Negative Schedule (PANAS): Construct validity, measurement properties and normative data in a large non-clinical sample. British Journal of Clinical Psychology, 43, 245-265. doi:10.1348/0144665031752934.

Garofalo, C., Neumann, C. S., Zeigler-Hill, V., \& Meloy, J. R. (2018). Spiteful and contemptious: A new look at the emotional experiences related to psychopathy. Personality Disorders: Theory, Research, and Treatment, 10, 173-184. doi. org/10.1037/per0000310.

Gordts, S., Uzieblo, K, Neumann, C., Van den Bussche, \& Rossi, G. (2017). Validity of the Self-Report Psychopathy scales (SRP-III full and short versions) in a community sample. Assessment, 24, 308-324. doi:10.1177/1073191115606205.

Falkenbach, D., Poythress, N., Falki, M., \& Manchak, S. (2007). Reliability and validity of two self-report measures of psychopathy. Assessment, 14, 341-350. doi:10.1177/1073191107305612.

Hare, R. D. (1991). The Hare psychopathy Checklist-Revised. Toronto, Canada: MultiHealth Systems.

Hare, R. D. (2003). The Hare Psychopathy Checklist-Revised manual (2nd ed.), Toronto, Ontario, Canada: Multi-Health Systems.

Hodson, G., Hogg, S. M., \& MacInnis, C. C. (2009). The role of „dark personalities“ (narcissism, Machiavellianism, psychopathy), Big Five personality factors, and ideology in explaining prejudice. Journal of Reserach in Personality, 43, 686-690. doi.org/10.1016/j.jrp.2009.02.005

Hicks, B. M., \& Patrick, C. J. (2006). Psychopathy and negative emotionality: Analysis of suppressor effects reveal distinct relations with emotional distress, fearfulness, and anger-hostility. Journal of Abnormal Psychology, 115, 276-287. doi:10.1037/0021-843X.115.2.276.

Jonason, P. K. (2014). Personality and politics. Personality and Individual Differences, 71, 181-184. doi.org/10.1016/j.paid.2014.08.002.

Jost, J. T. (2006). The end of the end of ideology. American Psychologist, 61, 651-670. doi:10.1037/0003-066X.61.7.651.

Jost, J. T., Federico, C. M., \& Napier, J. L. (2009). Political ideology: Its structure, functions, and elective affinities. Annual Review of Psychology, 60, 307-337. doi:10.1146/annurev.psych.60.110707.163600. 
Jost, J. T., Federico, C. M., \& Napier, J. L. (2013). Political ideologies and their social psychological functions. In M. Freeden, L. T. Sargent, \& M. Stears (Eds.). The Oxford handbook of political ideologies (pp. 232-250). Oxford, UK: Oxford University Press.

Jost, J. T., Glaser, J., Kruglanski, A. W., \& Sulloway, F. (2003). Political conservatism as motivated social cognition. Psychological Bulletin, 129, 339-375. doi:10.1037/0033-2909.129.3.339

Jost, J. T., \& Napier, J. L. (2012). The uncertainty-threat model of political conservatism. In M. A. Hogg, \& D. L. Blaylock (Eds.), Extremism and the psychology of uncertainty (pp. 90-111). Chichester UK: Blackwell Publishing Ltd.

Lilienfeld, S. O., Latzman, R. D., Watts, A. L., Smith, S. F., \& Dutton, K. (2014). Correlates of psychopathic personality traits in everyday life: Results from a large community survey. Frontiers in Psychology, 5, 1-11. doi:10.3389/ fpsyg.2014.00740.

Love, A. B., \& Holder, M. D. (2014). Psychopathy and subjective well-being. Personality and Individual Differences, 66, 112-117. doi:10.1016/j.paid.2014.03.033.

Mahmut, M. K., Menictas, C., Stevenson, R. J., \& Homewood, J. (2011). Validating the factor structure of the Self-Report Psychopathy Scale in a community sample. PsychologicalAssessment, 23, 670-678. doi:10.1037/a0023090.

Međedović, J. (2015). Nomološka mreža psihopatije [Nomological network of psychopathy]. Beograd: Institut za kriminološka i sociološka istraživanja.

Međedović, J., \& Petrovic, B. (2016). Can there be an immoral morality? Dark personality traits as predictors of moral foundations. Psihologija, 49(2), 185-197. doi:10.2298/psi1602185m

Međedović, J., Wertag, A., \& Sokić, K. (2018). Can psychopathic traits be adaptive? Sex differences in relations between psychopathy and emotional distress. Psihologijske teme, 27(3), 481-497. https://doi.org/10.31820/pt.27.3.7

Mehrabian, A. (1996). Relations among political attitudes, personality, and psychopathology assessed with new measures of Libertarianism and Conservatism. Basic and Applied Social Psychology, 18, 469-491. doi:10.1207/s15324834basp1804_7.

Neumann, C. S., Hare, R. D., \& Newman, J. P. (2007). The superordinate nature of the Psychopathy Checklist-Revised. Journal of Personality Disorders, 21, 102-117. doi:10.1521/pedi.2007.21.2.102.

Neumann, C. S., Hare, R. D., \& Pardini, D. A. (2014). Antisociality and the construct of psychopathy: Dana from across the globe. Journal of Personality, 83, 678-692. doi:10.1111/jopy.12127.

Neumann, C. S., \& Pardini, D. (2014). Factor structure and construct validity of the Self-Report Psychopathy (SRP) scale and the Youth Psychopathy Traits Inventory (YPI) in young men. Journal of Personality Disorders, 28, 419-433. doi:10.1521/pedi_2012_26_063.

Neumann, C. S., Vitacco, M. J., \& Mokros, A. S. (2016). Using both variable-centered and person-centered approaches to understanding psychopathic personality. In C. B. Gacono (ed.), The clinical and forensic assessment of psychopathy: A Practitioner's Guide, 2nd ed., pp. 14-31. Routledge: New York.

Niel, T. M. S., \& Selbom, M. (2012). Examining the factor structure of the Hare SelfReport Psychopathy Scale. Journal of Personality Assessment, 94, 244-253. doi:1 0.1080/00223891.2011.648294. 
Nail, P. R., McGregor, I., Drinkwater, A. E., Steele, G. M., \& Thompson, A. W. (2009). Threat causes liberals to think like conservatives. Journal of Experimental Social Psychology, 45(4), 901-907. https://doi.org/10.1016/j.jesp.2009.04.013

Nunnally, J. C., \& Bernstein, I. H. (1994). Psychometric theory (3rd ed.). New York, NY: McGraw-Hill.

Pačić-Turk, Lj., \& Gajski, M. (2014). Samoizvješće psihopatije SRP-III i povezanost njegovih dimenzija s Velepetorim modelom ličnosti [The Self-Report Psychopathy Scale SRP-III and its correlation with the Five Factor Model]. Društvena istraživanja, 23, 155-175. doi.org/10.5559/di.23.1.08.

Patrick, C. J. (1994). Emotions and Psychopathy: Startling new insights. Psychophysiology, 31, 276-287. doi:10.1111/j.1469-8986.1994.tb02440.x.

Paulhus, D. L., Neumann, C. S., \& Hare, R. D. (2017). Manuel for the Self-Report Psychopathy Scale (4th ed.). Toronto, Ontario: Multi-Health Systems.

Petrović, B. (2020). Leksički model socijalnih stavova: studija na srpskom jeziku [Lexical model of social attitudes: the study in Serbian language]. Institut za kriminološkaisociološkaistraživanja: Beograd, Srbija.

Preston, O. C., \& Anestis, J. C. (2018). Psychopathic traits in politics: Examining affiliation, support of political issues, and the role of empathy. Personality and Individual Differences, 131, 142-149. doi:10.1016/j.paid.2018.04.034.

Serafini, K., Malin-Mayor, B., Nich, C., Hunkele, K., \& Carroll, K. M. (2016). Psychometric properties of the Positive and Negative affect Schedule (PANAS) in a heterogeneous sample of substance users. The American Journal of Drug and Alcohol Abuse, 42, 203-212. doi:10.3109/00952990.2015.1133632.

Sibley, C. G., Osborne, D., \& Duckitt, J. (2012). Personality and political orientations: Meta-analysis and test of a Threat-Constraint Model. Journal of Research in Personality, 45, 664-677. doi:10.1016/j.jrp.2012.08.002.

Šram, Z. (2016). Materijalistička i prosocijalna orijentacija, desna autoritarnost i orijentacija socijalnoj dominaciji kao prediktori ideoloških obrazaca kod građana istočne Slavonije i Baranje [Materialistic value orientation and prosocial orientation, right-wing authoritarianism, and social dominance orientation as predictors of ideological patterns within the community sample of east Slavonija and Baranja]. U: D. Babić, A. Vukić, \& F. Škiljan (Eds.), Slavonija - hrvatska i europska regija (Slavonija. The Croatian and European Region (pp. 67-101). Zagreb: Institut za migracije i narodnosti.

Šram, Z. (2017). Comorbidity of psychopathy and depression: Across different ethnic and sex groups. The International Journal of Indian Psychology, 4, 98-109.

Šram, Z. \& Dulić, J. (2015). National threat perception, dominance-submissive authoritarian syndrome and totalitarian socialist ideology. International Journal of Humanities and Social Science, 5, 37-51.

Van Hiel, A., \& Kossowska, M. (2006). Having few positive emotions, or too many negative feelings? Emotions as moderating variables of authoritarianism effects on racism. Personality and Individual Differences, 40(5), 919-930. https://doi. org/10.1016/j.paid.2005.09.014

Verhulst, B., Eaves, L. J., \& Hatemi, P. K. (2012). Correlation not causation: The relationship between personality traits and political ideologies. American Journal of Political Science, 56, 34-51. www.jstor.org/stable/23075142. 
Veronese, G., \& Pepe, A. (2017). Positive and Negative affect in children living in refugee camps: Assessing the psychometric proprieties and factorial invariance of the PANAS-C in Gaza Strip. Evaluation \& the Mental Professions, 40, 3-32. doi:10.1177/0163278715625741.

von Humboldt, S., Monteiro, A., \& Leal, I. (2017). Validation of the PANAS: A measure of positive and Negative affect for use with cross-national older adults. Review of European Studies, 9, 10-19. doi:10.5539/res.v9n2p10.

Watson, D., Clark, L. A., \& Tellegen, A. (1988). Development and validation of brief measures of positive and Negative affect: The PANAS scales. Journal of Personality and Social Psychology, 54, 1063-1070. doi:10.1037/0022-3514.54.6.1063.

\section{Appendix}

Factor structure of the Positive and Negative affect Schedule (PANAS)

\begin{tabular}{lll}
\hline Items & PA & NA \\
\hline 9. Enthusiastic & 0.78 & \\
14. Inspired & 0.76 & \\
3. Excited & 0.75 & \\
10. Proud & 0.74 & \\
17. Attentive & 0.72 & \\
16. Determined & 0.72 & \\
19. Active & 0.72 & \\
5. Strong & 0.68 & \\
1. Interested & 0.69 & \\
12. Alert & 0.40 & \\
18. Jittery & & 0.76 \\
15. Nervous & & 0.75 \\
2. Distressed & & 0.75 \\
7. Scared & & 0.73 \\
20. Afraid & & 0.73 \\
13. Ashamed & & 0.68 \\
11. Irritable & & 0.63 \\
4. Upset & & 0.63 \\
8. Hostile & & 0.63 \\
6. Guilty & & 0.60 \\
\hline
\end{tabular}




\section{Psihopatija i Raspored pozitivnog i negativnog afekta (PANAS) kao prediktori Totalitarne Političke Ideologije}

\section{Zlatko Šram}

Hrvatski centar za primjenjena društvena istraživanja

Ova studija imala je dva cilja: prvi je bio da se utvrdi da li su potreba za sigurnošću i socijalnom regulacijom nametnutom od vlade, prihvatanje življenja u diktaturi, ograničenja i osporavanje individualnih sloboda i podrška represivnim metodama i procedurama u tako visokim korelacijama da formiraju koherentnu latentnu dimenziju Totalitarne Političke Ideologije (TPI). Drugi cilj je bio da se istraži da li se psihopatske crte (Interpersonalna manipulacija, Površni afekt, Neobuzdani životni stil i Antisocijalno ponašanje) i PANAS (Raspored pozitivnog i negativnog afekta kao mera generalnog afektiviteta) nalaze u pozadini Totalitarne Političke ideologije. Istraživanje je izvršeno na uzorku ispitanika koji su trenutno pohađali ili su završili neki od fakulteta Univerziteta u Zagrebu ( $\mathrm{N}=386)$. Rezultati su pokazali da Totalitarna Politička Ideologija predstavlja koherentan i stabilan obrazac političkih uverenja i vrednosti. Kako bi se utvrdilo na koji način su psihopatija i PANAS povezani sa Totalitarnom Političkom Ideologijom sprovedena je multipla linearna regresija. Interpersonalna manipulacija, Površni afekt i Negativni afektivitet iz PANAS-a su bili značajni prediktori sa pozitivnim predznakom dok je Neobuzdani životni stil predviđao Totalitarnu Političku Ideologiju sa negativnim predznakom. Oko $15 \%$ varijanse Totalitarne Političke Ideologije bilo je objašnjeno ovim ličnosnim karakteristikama. Nalazi imaju i teorijski i praktični značaj kada je u pitanju razumevanje usvajanja totalitarnih ideoloških uverenja.

Ključne reči: psihopatija, negativni afekat, ideologija, totalitarizam 